\title{
Ischaemic changes in electrocardiography (ECG) after attempted suicide by hanging (transient left ventricular apical ballooning)
}

\author{
"MKN Ratnayake ${ }^{1}$, C Pathiraja ${ }^{2}$, AN Ranathunga ${ }^{3}$ \\ Medical Officer, Anaesthesia/ICU ${ }^{1}$; Consultant Anaesthetist ${ }^{2}$, Medical Officer ${ }^{3}$, Emergency Treatment \\ Unit, Provincial General Hospital, Ratnapura, Sri Lanka.
}

*Corresponding author: namalrath10@yahoo.com

\begin{abstract}
A 19 year old girl presented with extensive T inversions on ECG after attempted suicide by hanging. Her past medical history was normal. 2D-echo findings and troponin I were negative. These ECG changes were present over a 9 weeks duration without any clinical features and got completely cured. This is called Apical Ballooning Syndrome (ABS) which mimics acute coronary syndrome.
\end{abstract}

Key words: hanging; ECG changes

\section{Introduction}

Transient left ventricular apical ballooning or 'broken heart syndrome,' also called Takotsubo cardiomyopathy, is a cardiac condition that mimics the clinical presentation of acute coronary syndrome. The phenomenon of transient apical ballooning induced by emotional stress was first described in Japan and has a predisposition for postmenopausal females. ${ }^{1}$ It is characterized by an akinetic left ventricular apex that takes an elliptical shape with normal coronary arteries. In ventriculogram, it shows as ballooning out of the apex and hence the name was given as Apical Ballooning Syndrome (ABS). The aetiology of this stress-induced cardiomyopathy is yet unclear. Catecholamines seem to be a triggering factor. ${ }^{2}$ Excessive catecholamine stimulation may result in direct cardiac myocyte toxicity and also lead to microvascular endothelial dysfunction or spasm. ${ }^{3}$ ABS is reported in extreme physical or emotional stress $^{4}$ and attempted suicidal hanging. ${ }^{5}$ We report a patient with Apical Ballooning Syndrome presenting as deep $\mathrm{T}$ inversions in electrocardiogram (ECG) after attempted suicide by hanging.

\section{Case report}

A 19 year old girl was admitted to emergency treatment unit after attempted suicide by hanging. On admission, she was confused, restless, dyspnoeic and complained of chest pain. Her pupils were equally reacting to light and Glasgow Coma Scale was 9/15 (E-3, M-4, V-2). Her blood pressure was $86 / 60 \mathrm{mmHg}$, pulse rate was $100 / \mathrm{min}$ and $\mathrm{SpO}_{2} 96 \%$ on room air. She was electively intubated and transferred to ICU for mechanical ventilation. Her 12 lead ECG done on admission was normal (Figure 1).

Figure 1: ECG on admission
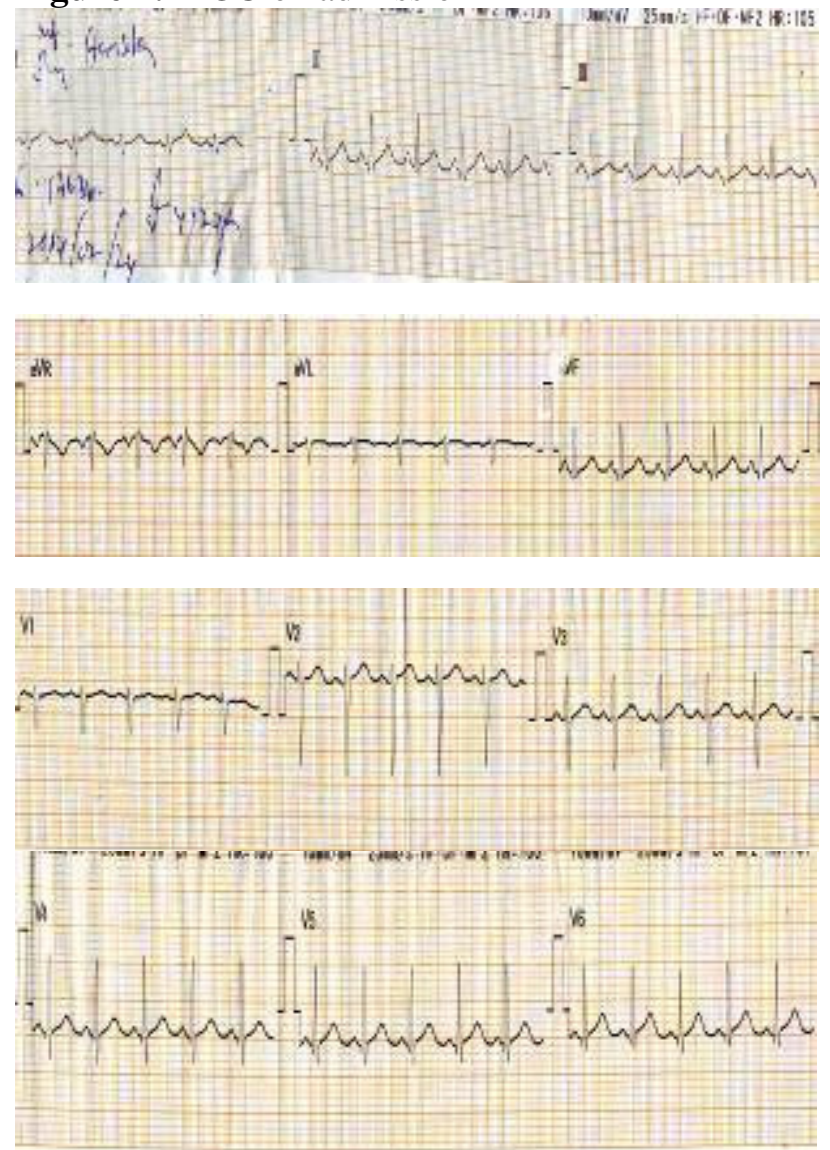
Propofol infusion was started and continued for the next 24 hours. Systolic blood pressure became more than $100 \mathrm{mmHg}$ with 2 boluses of $200 \mathrm{ml}$ normal saline. ECG was repeated in 4hours time and $\mathrm{T}$ wave inversions were noted in Lead I, II, $\mathrm{aVL}$, and $\mathrm{V}_{2}-\mathrm{V}_{6}$. (Figure 2)

Figure 2: ECG- 4hours after the admission


Next morning as she was conscious and rational, after the leak test, she was extubated. Following extubation throughout her hospital stay, she had stable haemodynamic parameters. Time to time she complained of mild retrosternal chest pain. Serial ECG showed progression into deep T wave inversions and new one appearing in $\mathrm{V}_{1}$. (Figure 3)
Figure 3: ECG- 44hours after the admission


Troponin I was negative and no abnormality was found in 2D echocardiogram. We were unable to do a ventriculogram or coronary angiogram. Chest pain was managed with paracetamol. During her ICU stay enoxaparin 40mg was given daily. Her initial serum $\mathrm{K}^{+}$level was $3.6 \mathrm{mmol} / \mathrm{L}$ (3.5-5.1) and repeat measurements were found to be within normal levels. Following investigations were done during her ICU stay. $\mathrm{Na}^{+} 140 \mathrm{mmol} / \mathrm{L}$, WBC $12 \mathrm{x}$ $10^{3} / \mu \mathrm{L}$, neutrophils $40 \%$, lymphocytes $58 \%$, platelets $220 \times 10^{3} / \mu \mathrm{L}, \mathrm{Hb} 12.1 \mathrm{~g} / \mathrm{dL}$, blood urea $3.5 \mathrm{mmol} / \mathrm{L}$, creatinine $92 \mu \mathrm{mol} / \mathrm{L}$, SGOT $78 \mathrm{U} / \mathrm{I}$, SGPT 44U/I. There were no changes seen in chest $\mathrm{X}$-ray and cervical spine x-rays. After 3 days of ICU treatment, she became completely normal and was transferred to the surgical ward. After discharge from hospital she was followed up with serial ECGs which became normal after about 9 weeks of the incident. (Figure 4) 
Figure 4: ECG- 9 weeks after the admission


\section{Discussion}

In our patient the first ECG change was noted by 4-5 hours following the initial incident and $\mathrm{T}$ inversions became deep over the next 48 hours. As she complained of retrosternal chest pain cardiac enzyme assay was done and became negative. At this stage we were reluctant to diagnose this as acute coronary syndrome because the patient was a teenage girl and had no significant past medical history or family history of heart disease. But to be safe it was decided to start prophylactic low molecular weight heparin. Transient left ventricular dysfunction associated with attempted suicide by hanging or accidental strangulation has been previously described. ${ }^{5,6,7}$

Myocardial perfusion studies using single photon emission computed tomography (SPECT) and technetium-99 tetrofosmin tomographic myocardial imaging indicate reversible myocardial ischemia in $\mathrm{ABS}$, in the absence of coronary artery occlusion. ${ }^{8}$ ECG changes such as $\mathrm{T}$ wave inversion, ${ }^{5,9} \mathrm{ST}$ elevation, QT prolongation and $\mathrm{U}$ waves ${ }^{9}$ have been previously reported in partial hanging.

\section{References}

1. Sato H, Tateishi H, Uchida T et al. TakoTsubo-like left ventricular dysfunction due to multi vessel coronary spasm. In: Kodama K, Haze K, Hori M, editors. Clinical aspect of myocardial injury: from ischemia to heart failure. Tokyo: Kagakuhyoronsha Publishing Company; 1990. pp. 56-64. PMid:2239249

2. Wittstein IS, Thiemann DR, Lima JA et al. Neurohumoral features of myocardial stunning due to sudden emotional stress. $N$ Engl J Med. 2005;352: 539-48. http://dx.doi.org/10.1056/NEJMoa043046 PMid:15703419

3. Ako J, Sudhir K, Farouque HM et al. Transient left ventricular dysfunction under severe stress: Brainheart relationship revisited. Am J Med. 2006;119:10-7. http://dx.doi.org/10.1016/j.amjmed.2005.08.022 PMid:16431176

4. Pollick C, Cujec B, Parker S, Tator C. Left ventricular wall motion abnormalities in subarachnoid hemorrhage: An echocardiographic study. J Am Coll Cardiol. 1988;12:600-5. http://dx.doi.org/10.1016/S0735-1097(88)80044-5

5. Chacko J, Brar G., Elangovan A., Moorthy R. Apical ballooning syndrome after attempted suicidal hanging. Indian J Crit Care Med. 2011 Jan-Mar; 15(1): 43-45.

http://dx.doi.org/10.4103/0972-5229.78225

PMid:21633546 PMCid:PMC3097542

6. Gnanavelu G, Sathiakumar DBD. Reversible left ventricular dysfunction in suicidal hanging. J Assoc Physicians India. 2008;56:545-6.

PMid:18846910

7. Valletta ME, Haque I, Al-Mousily F et al. Hanging causing severe reversible left ventricular dysfunction. Pediatr Crit Care Med. 2008;9:47-50. http://dx.doi.org/10.1097/PCC.0b013e31818e370e PMid:18997592

8. Ito K, Sugihara $\mathrm{H}$, Katoh $\mathrm{S}$ et al. Assessment of Takotsubo (ampulla) cardiomyopathy using 99mTc-tetrofosmin myocardial SPECTcomparison with acute coronary syndrome. Ann Nucl Med. 2003;17:115-22. http://dx.doi.org/10.1007/BF02988449 PMid:12790360 
9. Aslam M, Maurya SP. ECG changes in a case of attempted partial hanging. Journal of Forensic and Legal Medicine 2013 July;20(5): 546-54. http://dx.doi.org/10.1016/j.jflm.2013.03.011

PMid:23756532 